Acta vet. scand. $1977,18,433-441$.

From the Agricultural Research Organization, Volcani Center, Bet Dagan, Israel, and the Department of Physiology, Endocrinology and Bloodgrouping, Royal Veterinary and Agricultural University, Copenhagen, Denmark.

\title{
PATERNITY TESTS IN MULTISIRED BEEF HERDS BY BLOOD GROUPING*
}

By

\author{
A. R. Lehrer ${ }^{\star \star}$, M. B. Brown ${ }^{\star \star \star}$, H. Schindler ${ }^{\star \star}$, Z. Holzer ${ }^{\star \star}$ \\ and $B$. Larsen La $^{\star \star}$
}

LEHRER, A. R., M. B. BROWN, H. SCHINDLER, Z. HOLZER and B. LARSEN: Paternity tests in multisired beef herds by blood grouping. Acta vet. scand. 1977, 18, 433-441. - The number of offspring sired by individual bulls in multisired beef herds was determined by blood grouping. Six series of tests, each having from 3 to 18 bulls as possible sires, yielded from 35 to 114 dam-offspring pairs. The paternity was established for 45 to $90 \%$ of the calves tested in each series. The rest were cases with either more than 1 bull not being excluded as the possible sire, or all bulls excluded from being the sire. The causes for the non-established paternities are discussed. Highly significant differences were found in the number of offspring sired by each bull. In each series, bulls ranking in the top third of the siring order sired $65-100 \%$ of the calves with established paternities. Since a minority of the bulls sired the majority of the calf-crop, the generally recomended number of bulls for herds on the range can perhaps be reduced.

paternity tests; beef herds; blood grouping; sire prolificacy.

Under common managerial practices, the contribution of individual bulls of the total calf-crop in multisired beef herds is unknown. However, individual variations in the number of offspring can be assumed to exist, since bulls differ from each other in semen production, libido and mating performance ( $\mathrm{Ha}$ fez \& Schein 1962, Fechheimer 1970, Lodge \& Salisbury 1970, Alexander et al. 1974).

* Contribution from the Agricultural Research Organization, The Volcani Center, Bet Dagan, Israel.

* * Institute of Animal Science, A.R.O.

* * Department of Statistics, Tel Aviv University, Tel Aviv, Israel.

$\star \star \star \star$ Department of Physiology, Endocrinology and Bloodgrouping, R.V.A.U. 
In the present study, the paternity of the calves in multisired beef herds was determined by blood grouping in order to clarify whether, and if so to what extent, the expected individual variation in the proportion of the calf-crop sired by each bull does exist.

\section{MATERIALS AND METHODS}

Six series of paternity tests were performed in commercial herds on offspring born during the period September 1972 through February 1973 (Series Nos. 1, 2, 3), September 1973 through February 1974 (Series No. 4), and September through November 1974 (Series Nos. 5, 6). Series Nos. 3 and 4 were performed in the same herd.

The dams were of the local Arab breed, Hereford crosses, and pure or crossbred Brahmans. The bulls were of pure or crossbred Charolais, Simmental, Hereford and Brahman origin. In Series No. 1, the bulls were $2-3$ years old and kept at a ratio of 1 to about 10 cows. In the other series, they were 2-5 years old and kept at a ratio of 1 to about 25 cows.

Calving took place on the range. Within a week post partum the calves were marked with ear tags, and their mothers were identified. Blood samples were obtained after the end of the calving season from animals that retained their ear tags. Due to death and loss of identity, only part of the calf-crop was bloodtyped.

The paternity of the calves was examined by testing blood samples from dam-offspring pairs and the possible sires for 56 blood group factors belonging to 10 blood group systems and for 4 polymorphic protein systems, following the methods described by Larsen \& Moustgaard (1972).

\section{RESULTS AND DISCUSSION}

\section{Ratio of established paternities}

From the results presented in Table 1, it can be seen that paternities were established for some of the tested offspring only. The non-established paternities were either cases in which all bulls were excluded from being the sire, or cases in which 2 to 4 bulls could not be excluded as possible sires.

Cases in which all mating bulls were excluded from being the sire ("all bulls excluded") resulted from 1 of 2 causes: 1) The 
T a b l e 1. Results of paternity tests in multisired beef herds.

\begin{tabular}{|c|c|c|c|c|c|}
\hline \multirow{2}{*}{$\begin{array}{c}\text { Series } \\
\text { No. }\end{array}$} & \multirow{2}{*}{$\begin{array}{c}\text { Number } \\
\text { of } \\
\text { tested } \\
\text { bulls }\end{array}$} & \multirow{2}{*}{$\begin{array}{c}\text { Number } \\
\text { of dam- } \\
\text { off spring } \\
\text { pairs }\end{array}$} & \multicolumn{3}{|c|}{ Percentage of calves with } \\
\hline & & & $\begin{array}{l}\text { "established } \\
\text { paternities" }\end{array}$ & $\begin{array}{c}\text { "2-4 possible } \\
\text { sires" }\end{array}$ & $\begin{array}{l}\text { "all bulls } \\
\text { excluded" }\end{array}$ \\
\hline 1 & 18 & 82 & 44 & 34 & 22 \\
\hline 2 & 7 & 114 & 64 & 4 & $32^{\star}$ \\
\hline $\mathbf{3}$ & 7 & 88 & 73 & 18 & 9 \\
\hline 4 & 10 & 75 & 57 & 28 & 15 \\
\hline 5 & 3 & 36 & 78 & 0 & 22 \\
\hline 6 & 3 & 35 & 91 & 0 & 9 \\
\hline
\end{tabular}

* Offspring from an 8th bull, which died at the end of the breeding season and was not blood typed, may be included in these cases.

offspring were sired by maturing calves born outside of the regular calving season and therefore still running with their dams during the following breeding season; or 2) false identification of the mother. The latter is more likely to occur with calves born on the same day and could be demonstrated in 3 cases, where the blood groups excluded the alleged cow as possible dam.

Cases where more than 1 bull could not be excluded as the possible sire result from a similarity in blood type between 2 or more bulls. This occurred in Series No. 3, where the same 2 bulls could not be excluded as the possible sires of 9 out of 11 offspring. The likelihood of not being able to exclude all but 1 bull as possible sire, due to chance, increases with an increase in the number of bulls in the herd. This is demonstrated in Series No. 1, in which 18 bulls were involved and where $34 \%$ of the cases could not be solved (" $2-4$ possible sires"), in contrast to Series Nos. 5 and 6 with only 3 bulls involved and where none of the cases resulted in more than 1 bull as possible sire.

Following the principles of Wiener et al. (1930), the probability, $P_{n}$, of excluding all but the true sire by means of blood grouping in multisired herds can be calculated from the equation $P_{n}=P(n-1)$, where $n$ is the number of bulls in the herd and $P$ is the probability of excluding a random bull as possible sire (Abe et al. 1971). The value of $\mathrm{P}$ depends on the number of blood group system used and the number and frequencies of the alleles within each system.

In order to judge the efficiency of the paternity tests in the present data and to compare the results obtained in the 6 series, 
the above equation was solved with regard to $P_{n}$ for each of the series using the number of calves with established paternity and with " $2-4$ possible sires". For this purpose a common $P$ was estimated for the 6 series as follows: A value for $P$ was assumed, and the expected numbers of calves with established paternity and more than 1 possible sire were calculated for each series and compared with the actual observed number in a $\chi^{2}$ test. $P$ was varied, until a minimum $\chi^{2}$ value was achieved. The $P$ value which minimized the $\chi^{2}$ statistics was found to be 0.97 . However, the $\chi^{2}$ test was significant $\left(\chi^{2}=14.7\right.$ for 5 d.f., $\left.P<0.025\right)$, indicating heterogeneity among the 6 series of data with regard to the efficiency of the paternity test. The major contribution of the $\chi^{2}$ was found in series No. 2, in which the number of actual established paternities was larger than expected on the basis of $\mathbf{P}=0.97$. Omitting this series, a common $\mathbf{P}$ value for the remaining 5 series was estimated to be 0.965 and yielding a nonsignificant $\chi^{2}$ test. In Table 2 the number and percentage of calves with established and non-established paternities (" $2-4$ possible sires") in each of the 6 series are compared with the respective expectations, using $\mathrm{P}=0.965$.

The above estimated $P$ values based upon the data in the present study are high compared with values obtained on a theoretical basis in some purebred cattle breeds. Thus, based on gene frequencies in 12 blood group and protein systems, Larsen

T a b l e 2. The actual vs. expected number of calves with established paternities and with more than 1 possible sire (the calculated numbers are based on $P=0.965$ ).

\begin{tabular}{|c|c|c|c|c|}
\hline \multirow{2}{*}{$\begin{array}{l}\text { Series } \\
\text { No. }\end{array}$} & \multicolumn{2}{|c|}{ Actual number of calves with } & \multicolumn{2}{|c|}{ Expected number of calves with } \\
\hline & $\begin{array}{c}\text { established } \\
\text { paternities }\end{array}$ & $\begin{array}{c}\text { more than one } \\
\text { possible sire }\end{array}$ & $\begin{array}{l}\text { established } \\
\text { paternities }\end{array}$ & $\begin{array}{l}\text { more than one } \\
\text { possible sire }\end{array}$ \\
\hline 1 & $36(56.2)^{\star}$ & $28(43.8)$ & $34.9(54.5)$ & $29.1(45.5)$ \\
\hline 2 & $73(94.8)$ & $4(5.2)$ & $62.2(80.8)$ & $14.8(19.2)$ \\
\hline 3 & $64(80.0)$ & $16(20.0)$ & $64.6(80.7)$ & $15.4(19.3)$ \\
\hline 4 & $43(67.2)$ & $21(32.8)$ & $46.4(72.5)$ & $17.6(27.5)$ \\
\hline 5 & $28(100.0)$ & $0(0.0)$ & $26.1(93.2)$ & $1.9(6.8)$ \\
\hline 6 & $32(100.0)$ & $0(0.0)$ & $29.8(93.1)$ & $2.2(6.9)$ \\
\hline
\end{tabular}

$\chi^{2}=15.2$ with 5 degrees of freedom $(\mathrm{P}<.01)$.

If Series 2 is omitted from the calculations, $\chi^{2}=5.4$ with 4 degrees of freedom $(.20<\mathrm{P}<.30)$.

* The percentage is in parentheses. 
\& Moustgaard (1972) reported the probability of excluding a random bull as possible sire to be $93 \%$ in the Red Danish dairy cattle; in the Japanese Shorthorn, $A$ be et al. estimated $\mathrm{P}=85 \%$ on the basis of gene frequencies in 14 systems. The high efficiency obtained in the present study is probably due to a high degree of heterogeneity with regard to blood groups in the material, resulting from the bulls and cows being of different breeds or crossbred animals.

\section{The individual sire's contribution to the calf-crop}

This was assessed using the number of calves sired by each bull in a series. However, in this way, only part of the calf-crop served for the assessment, due to loss of identity or death before blood sampling, and the involvement of more than 1 bull in the possible paternity. Whereas the first limitation can be reduced by proper management, the second one is unavoidable. The possibility of overcoming the latter difficulty was tested by assessing the numer of calves by each bull in 2 different ways: 1) the estimated number of offspring is equal to the number of established paternities; and 2) since in all series varying numbers of unestablished paternities were found, the estimated number of offspring was calculated by adding to the number of the bull's established paternities a number of calves which could be assigned to him out of the cases with " $2-4$ possible sires". The offspring with "all bulls excluded" were not taken into account. Two methods, "no knowledge" and "hindsight knowledge", were used for the calculations" : if there were $K_{J}$ non-excluded sires

* The 3 methods of estimating the number of offspring per bull can be expressed as:

a) Established paternities only, $\quad \mathrm{S}_{\mathrm{i}}=\mathrm{E}_{\mathrm{i}}$

b) The method of "no knowledge", $\quad S_{i}=E_{i}+\Sigma\left(1 / K_{J}\right)$

c) The method of "hindsight knowledge", $S_{i}=E_{i}+\stackrel{J(i)}{\Sigma\left(S_{i} / \Sigma S_{m}\right)}$

where $S_{i}=$ estimated number of offspring for bull (i)

$\mathrm{E}_{\mathrm{i}}=$ number of established paternities for bull (i)

$\mathbf{K}_{\mathrm{J}}=$ number of possible sires for calf $(\mathrm{J})$, where $\mathrm{K}_{\mathrm{J}}>1$

$\Sigma=$ summation over calves $(\mathrm{J})$ for which bull (i) is a pos$\mathrm{J}(\mathrm{i})$ sible sire ("2-4 possible sires")

$\Sigma=$ summation over bulls $(\mathrm{m})$ which are the possible sires $\mathrm{m}(\mathrm{J})$ for calf $(\mathrm{J})$ ("2-4 possible sires")

Method (c) results in a set of simultaneous equations which can be solved for $S_{i}$. 
to a calf $(\mathrm{J})$, the "no knowledge" method was to assign $1 / \mathrm{K}_{\mathrm{J}}$ calf to each of these sires. This was done for each of the calves with "2-4 possible sires" and, by adding all the 'fractions' of calves assigned to a bull (i) to his established paternities $\left(E_{i}\right)$, his estimated number of offspring $\left(S_{i}\right)$ was obtained.

With the "no knowledge" method each of the possible sires of a calf is assumed to have an equal probability of having sired the calf. However, knowledge does exist from the established paternities of each bull, indicating different probabilities. If there were $\mathrm{K}_{\mathrm{J}}$ non-excluded sires to a calf $(\mathrm{J})$, the "hindsight knowledge" method was to assign to each of the sires a fraction of the calf proportional to the estimated number of offspring $\left(S_{1}\right)$ of each of these possible sires (the sum of the assigned fractions of a calf is unity). The estimated number of offspring $\left(S_{i}\right)$ of a bull (i) was equal to his established paternities $\left(E_{i}\right)$, plus additional 'fractions' from calves of which he was a possible sire. This set of equations -1 for each bull (i) in a series was solved simultaneously for the estimated numbers of offspring $\left(\mathrm{S}_{\mathrm{i}}\right)$.

To test the equality of the individual sire's contribution to the calf crop the usual $\chi^{2}$ test was applied, using either the established or the estimated number of paternities. The results presented in Table 3 confirm the assumption that bulls differ considerably from each other, since highly significant differences $(P<0.005)$ were found for each series in the number of offspring sired by each bull. The significant chi-squares occur when anyone of the 3 methods of assessing the number of calves sired by a bull is used, although some minor changes occurred in the "siring" rank of the bulls.

From Table 3 it can also be seen that a minority of the herd's bulls sire the majority of the calf-crop. In Series Nos. 2, 3 and 4, the first 3 among 7 or 10 bulls in each herd sired about $65 \%$, $86 \%$ and $79 \%$, respectively, of the offspring with established paternities. In Series Nos. 5 and 6, the highest ranking bull out of the 3 in each herd sired about $93 \%$ and $75 \%$, respectively, of the offspring with established paternities.

Six bulls in Series Nos. 3 and 4 served during 2 consecutive breeding seasons. Their share in the established paternities resulting from these 2 seasons is recorded in Table 4 . It can be seen that the siring ability and the "siring" rank order within each bull but 1 were very similar. The one bull which consider- 
T a b le 3. Ranking of bulls according to size of progeny group (established paternities per bull).

\begin{tabular}{|c|c|c|c|c|c|}
\hline \multirow[t]{2}{*}{ Siring rank } & \multicolumn{5}{|c|}{ Series No. } \\
\hline & 2 & 3 & 4 & 5 & 6 \\
\hline 1 st & $22(1 ; 2)^{*}$ & 22 & $19(2 ; 4)$ & 26 & 24 \\
\hline 2nd & 16 & $19(1 ; 1)$ & $8(4 ; 7)$ & 1 & 8 \\
\hline $3 r \cdot d$ & 9 & $14(6 ; 11)$ & 7 & 1 & 0 \\
\hline 4th & 8 & $4(0 ; 0)$ & $2(4 ; 4)$ & & \\
\hline 5 th & $7(2 ; 1)$ & $3(5 ; 2)$ & $2(3 ; 2)$ & & \\
\hline 6 th & $7(1 ; 1)$ & $1(2 ; 1)$ & 2 & & \\
\hline 7 th & 4 & $1(2 ; 1)$ & $1(4 ; 3)$ & & \\
\hline 8th & & & $1(2 ; 0)$ & & \\
\hline 9th & & & $1(1 ; 1)$ & & \\
\hline 10th & & & $0(1 ; 0)$ & & \\
\hline Total & $73(4 ; 4)$ & $64(16 ; 16)$ & $43(21 ; 21)$ & 28 & 32 \\
\hline \multicolumn{6}{|c|}{ Chi-square tests * } \\
\hline $\begin{array}{l}\text { Established } \\
\text { paternities only }\end{array}$ & $\chi^{2}=22.9$ & 53.0 & 70.7 & 42.5 & 28.0 \\
\hline $\begin{array}{l}\text { Estimated } \\
\text { paternities by } \\
\text { "no knowledge" }\end{array}$ & $\chi^{2}=24.6$ & 57.5 & 74.1 & & \\
\hline \multirow{2}{*}{$\begin{array}{l}\text { Estimated } \\
\text { paternities by } \\
\text { "hindsight } \\
\text { knowledge" }\end{array}$} & $\chi^{2}=22.6$ & 40.3 & 55.3 & & \\
\hline & $P<0.005$ & 0.005 & 0.005 & 0.005 & 0.005 \\
\hline
\end{tabular}

* In parentheses, the number of additional paternities assigned by the methods "no knowledge" and "hindsight knowledge", respectively.

* * For Series No. $1, \chi^{2}=35.0,34.3,48.7$, respectively; $\mathrm{P}<.005$.

ably increased its siring ability from the first to the second year was about 16 months old at the beginning of the first season. Due to the small amount of data, no statistical analysis was performed.

\section{Practical conclusions}

In the present study the proportion of the calf-crop sired by each bull was assessed under conditions of commercial husbandry. Therefore, we do not know whether the individual differences in the number of offspring originated in genetic factors, 
T a ble 4. The siring ability of the same bulls in 2 consecutive breeding seasons.

\begin{tabular}{|c|c|c|}
\hline \multirow[t]{2}{*}{ Bull } & \multicolumn{2}{|c|}{$\begin{array}{l}\text { Number (and, in parentheses, percentage) of } \\
\text { established paternities }\end{array}$} \\
\hline & $\begin{array}{l}\text { first breeding season } \\
\text { (Series No. 3) }\end{array}$ & $\begin{array}{l}\text { second breeding season } \\
\text { (Series No. 4) }\end{array}$ \\
\hline Ny5 & 22 (34) & 19 (44) \\
\hline Ny3 & $14(22)$ & 8 (19) \\
\hline Ny 6 * & 1 & 7 (16) \\
\hline Ny4 & $4 \quad(6)$ & $2 \quad(5)$ \\
\hline Ny2 & $3 \quad(5)$ & $2 \quad(5)$ \\
\hline Ny7 & 1 (2) & 1 (2) \\
\hline Other & $19(29)$ & $4 \quad(9)$ \\
\hline Total & $64(100)$ & $43(100)$ \\
\hline
\end{tabular}

* 16 months old at the beginning of the first breeding season.

environmental influences or social order. Nevertheless, the findings suggest that the usual 1:25 bull-to-cow ratio (Fox 1972) can be widened - a possibility which offers higher selection intensity and economic advantages. The practical use of paternity tests for this purpose has the disadvantage that the results are obtained long after the end, rather than before the beginning, of the breeding season. However, if a relationship can be found between the proportion of the calf-crop sired by a bull and its sexual behavior as tested before the breeding season, breeding bulls can be chosen according to their expected prolificacy.

\section{ACKNOWLEDGEMENTS}

Blood sampling was carried out by the veterinarians and technicians of the Governmental Veterinary Services, Afula and Ramla districts. The cooperation and help of the herdsmen in Kibbutz Sha'alvim and at the Newe Ya'ar Agricultural Experiment Station are gratefully acknowledged.

\section{REFERENCES}

Abe, T., T. Olshi, K. Mogi, M. Kanemaki \& T. Kurata: Paternity tests in pasturing cattle by blood grouping. Jap. J. vet. Sci. 1971, 33, 177 (Abstr.).

Alexander, G., J. P. Signoret \& E. S. E. Hafez: Sexual and maternal behaviour, chap. 10. In Reproduction in Farm Animals. E. S. E. Hafez, ed. Lea and Febiger, Philadelphia, Pa. 1974.

Fechheimer, N. S.: Genetic aspects of testicular development and function, chap. 1. In The Testis, Vol. III. A. D. Johnson, W. R. Gomes and N. L. VanDemark, eds. Acad. Press, New York 1970. 
Fox, F. W.: Range bull management, chap. 10. In Commercial Beef Cattle Production. C. C. O'Mary and I. A. Dyer, eds. Lea and Febiger, Philadelphia, Pa. 1972.

Hafez, E. S. E. \& M. W. Schein: The behaviour of cattle, chap. 10. In The Behaviour of Domestic Animals. Bailliere, Tindall and Cox, London 1962.

Larsen, B. \& J. Moustgaard: Blood groups and cattle breeding. Conference-paper No. 11. In 7th Int. Conf. World Jersey Cattle Bureau, Århus, Denmark 1972.

Lodge, J. R. \& G. W. Salisbury: Seasonal variation and male reproductive efficiency, chap. 4. In The Testis, Vol. III. A. D. Johnson, W. R. Gomes and N. L. VanDemark, eds. Acad. Press, New York 1970.

Wiener, A. S., M. Lederer \& S. H. Polayes: Studies in iso-hemagglutinations. IV. On the chances of proving non-paternity; with special reference to blood groups. J. Immunol. 1930, 19, 259282.

\section{SAMMENDRAG}

Faderskabsbestemmelse $i$ ekstensive kvæghold ved blodtypeundersøgelse.

Med henblik på at bestemme de enkelte tyres andel i antallet af kalve i st $\varnothing$ rre besætninger med løsdrift og naturlig bedækning, er der udført blodtypeunders $\varnothing$ gelse i fem besætninger. I en besætning omfatter unders $\emptyset$ gelsen to avlssæsoner. Herved er der udført ialt seks serier af faderskabsunders $\varnothing$ gelser, hver omfattende fra 34 til 114 moder-afkom par og med fra tre til 18 tyre som mulige fædre.

Ved blodtypeunders $\varnothing$ gelse kunne faderskabet fastlægges for mellem 45 og $90 \%$ af de unders $\varnothing$ gte kalve $\mathrm{i}$ de enkelte serier. For de resterende kalve kunne faderskabet ikke afgøres, idet der enten var mere end én tyr, der ikke kunne udelukkes som mulig fader, eller ingen af tyrene kunne være fader. De mulige årsager hertil er diskuteret.

Ved sammenligning af de enkelte tyres andel $i$ antallet af kalve fandtes statistisk sikre forskelle mellem tyre inden for besætning. Den bedste trediedel af tyrene med hensyn til antal kalve fandtes at være fader til mellem $65 \mathrm{og} 100 \%$ af kalvene med fastlagt faderskab i de enkelte besæetninger. Det synes derfor muligt at reducere det almindeligt anbefalede antal tyre pr. besætning under løsdriftforhold med naturlig bedækning.

(Received May 20, 1977).

Reprints may be requested from: A. R. Lehrer, the Institute of Animal Science, A.R.O., Volcani Center, P.O.Box 6, Bet Dagan, Israel, or B. Larsen, the Department of Physiology, Endocrinology and Bloodgrouping, Royal Veterinary and Agricultural University, 13 Bülowsvej, DK-1870 Copenhagen V, Denmark. 